\title{
Plant Regeneration from Petioles of Kiwifruit Microshoots
}

\author{
María Victoria González, Manuel Rey, and Roberto Rodríguez \\ Laboratorio de Fisiología Vegetal, Departamento Biología Organismos y \\ Sistemas, Universidad de Oviedo, E-33071 Oviedo, Spain
}

Additional index words. Actinidia deliciosa, callus culture, micropropagation, adventitious shoots, rooting

\begin{abstract}
A simple and reliable protocol for plant regeneration from petioles of micropropagated plants of kiwifruit [Actinidia deliciosa (A. Chev) Liang and Ferguson, var. deliciosa 'Hayward'] is described. Morphogenic callus was initiated by culturing petioles taken from in vitro-propagated plants. From the media tested, Cheng's K(h) medium plus $0.1 \mu_{\mathrm{M}}$ IAA, $4.5 \mu_{\mathrm{m}}$ zeatin, and $2 \%$ sucrose was the best for callus induction, maintenance, and shoot bud formation and development. Bases of developed shoots were immersed in 5 mм IBA for 15 seconds; subsequent culture in half-strength $K(h)$ basal medium achieved $82 \%$ rooting. Regenerated plantlets were successfully transplanted to soil with $\mathbf{9 7 \%}$ survival. Chemical names used: indole-3-acetic acid (IAA); indole-3-butyric acid (IBA); 2-methyl-4-(1H-purin-6-ylamino)-2-buten-1-ol (zeatin).
\end{abstract}

The kiwifruit industry, which has become important in the last decade, depends on a single cultivar ('Hayward'), which is cultivated worldwide because of its fruit quality. Although there are no serious agricultural problems with this fruit crop, many traits are open for improvement (Ferguson et al., 1990), including resistance to diseases and pests (Revilla et al., 1992). The genetic improvement of such traits and the study of physiological characteristics of kiwifruit, such as functional dioecism, could be facilitated by the availability of reliable protocols for transgenic plant production. These protocols are based on reliable plant regeneration systems.

In Actinidia deliciosa, adventitious plants have been regenerated from stem segments of field-grown plants (Leva and Bertocci, 1988), petiole segments of field-grown plants (Revilla and Power, 1988), hypocotyl and stem segments from seedlings (Uematsu et al., 1991), and leaf explants from in vitro-grown plants (Janssen and Gardner, 1993; Predieri et al., 1988; Rugini et al., 1991). Protocols for plant transformation also are available using hypocotyl and stem segments (Uematsu et al., 1991) and leaf explants from in vitro-grown plants (Janssen and Gardner, 1993; Rugini et al., 1991).

In our report, we describe a complete and reliable system for kiwifruit plant regeneration from callus induced on petioles of micropropagated plants. This system, which to our knowledge is being described for the first time, might be a useful alternative of regeneration for transformation of this species.

Received for publication 3 Oct. 1994. Accepted for publication 14 May 1995. The cost of publishing this paper was defrayed in part by the payment of page charges. Under postal regulations, this paper therefore must be hereby marked advertisement solely to indicate this fact.

\section{Materials and Methods}

Mature (5-year-old), field-grown, female kiwifruit ('Hayward') plants were micropropagated from shoot tips and were maintained in vitro as described by Standardi (1983). Leaf petioles (10 to $15 \mathrm{~mm}$ long) were taken from the basal parts of microshoots $>40 \mathrm{~mm}$ long from the eighth monthly subculture. Three positions of the kiwifruit explants onto the culture media were tested: horizontal, upright, and reversed upright.

Three basal media [K(h) (Cheng, 1975), MS (Murashige and Skoog, 1962) and St (Standardi, 1983)], each containing $0.1 \mu \mathrm{M}$ IAA and $4.5 \mu \mathrm{M}$ zeatin, were evaluated for callus induction. Callus proliferation was performed in $\mathrm{K}(\mathrm{h})$ and MS medium, either at fullor half-strength salts, containing $0.1 \mu \mathrm{M}$ IAA and 4.5 or $2.25 \mu \mathrm{M}$ zeatin. Two types of explants were isolated for transfer to induction medium independently based on the presence of visible buds on their surface. Type I consisted of callus with the primary explant, and type II was callus alone. Pieces ( 5 to $10 \mathrm{~mm}$ in diameter) of both types were transferred to MS or $\mathrm{K}(\mathrm{h})$ induction medium. In addition, pieces of type II explants were transferred to the same media, but the media contained half the mineral salts and zeatin concentrations.

For rooting, the basal part of isolated shoots (>10 mm long) was immersed in filter-sterilized IBA solution ( $5 \mathrm{~mm}$ ) for $15 \mathrm{sec}$, followed by transfer to half-strength $\mathrm{K}(\mathrm{h})$ basal medium. Regenerated plants were transferred to a 1 sterile peat : 1 perlite $(\mathrm{v} / \mathrm{v})$ substrate in 95 $\times 50$-mm baby-food glass jars for 10 days, with gradual opening of the glass cover. After that procedure, they were transferred to soil [1 peat : 1 perlite $(\mathrm{v} / \mathrm{v})]$ under a mist chamber ( $80 \%$ to $100 \%$ relative humidity) in a greenhouse.

All media contained 2\% sucrose. Before autoclaving, the $\mathrm{pH}$ was adjusted to 5.5 for $\mathrm{K}(\mathrm{h})$ and St media and to 5.8 for MS media. They all were solidified with $0.7 \%$ agar (bac- teriological agar type AB-50889; Roko S.A., Spain) and autoclaved for $15 \mathrm{~min}$ at $120 \mathrm{C}$ and $98 \mathrm{KPa}$. IAA was filter-sterilized $(0.45 \mu \mathrm{m}$ pore size) and always added to the lukewarm medium after it had been autoclaved.

All cultures were replicated at least six times in $95 \times 50$-mm baby-food glass jars containing $20 \mathrm{ml}$ of culture medium and two to three explants per jar. The explants were cultured in a growth chamber at $25 \pm 2 \mathrm{C}$ under a 16-h photoperiod $\left(15.6 \mu \mathrm{mol} \cdot \mathrm{m}^{-2} \cdot \mathrm{s}^{-1}\right.$, coolwhite fluorescent tubes). Percentage of callusing and organogenic responses and the number of shoot buds and developed shoots were recorded for each experiment 30 days after the experiment's initiation. Shoot bud primordia $\geq 5 \mathrm{~mm}$ long were considered as developed shoots.

Results were statistically evaluated using Pearson's $\chi^{2}$ test for frequency (percentages) comparisons among treatments. All other comparisons were performed by one-way analysis of variance followed by a least significant difference test for comparisons among sample means.

\section{Results and Discussion}

Green calli were formed at the cut ends of horizontally placed petioles in the three media tested (Table 1), all supplemented with $0.1 \mu \mathrm{M}$ IAA and $4.5 \mu \mathrm{M}$ zeatin. After 30 days of culture, the amount of callus produced was the lowest in St medium, with poor callus proliferation. Adventitious shoot buds grew on the surface of the neoformed callus. The frequency and number of adventitious shoot buds formed differed among the three media tested. Only calli produced on MS and $\mathrm{K}(\mathrm{h})$ were able to support bud formation. The most buds were obtained on $\mathrm{K}(\mathrm{h})$ medium (Table 1 ). In view of these results, St medium was not used for callus subculture.

Explants in the upright and reversed upright positions produced callus at the cut end in contact with the culture medium in all the media tested; however, no adventitious buds formed.

Explants containing callus plus part of the petiole (type I) and callus alone (type II) were subcultured in $\mathrm{K}(\mathrm{h})$ and MS media. All media tested supported additional callus growth, adventitious shoot bud formation, and shoot de-

Table 1. Effect of medium composition on callus formation and adventitious bud induction from petioles of micropropagated kiwifruit in the presence of $0.1 \mu \mathrm{M}$ IAA and $4.5 \mu \mathrm{m}$ zeatin after 30 days in culture.

\begin{tabular}{|c|c|c|c|}
\hline \multirow{2}{*}{$\begin{array}{l}\text { Culture } \\
\text { medium }^{\mathrm{z}}\end{array}$} & \multicolumn{2}{|c|}{ Explants forming (\%) } & \multirow{2}{*}{$\begin{array}{c}\text { Avg no. } \\
\text { shoot buds/ } \\
\text { explant (SE) }\end{array}$} \\
\hline & $\overline{\text { Callus }}$ & Shoot buds & \\
\hline$\overline{\mathrm{K}(\mathrm{h})}$ & 100 & $100 a^{y}$ & $22.3(1.5) \mathrm{a}^{\mathrm{x}}$ \\
\hline MS & 100 & $61.5 \mathrm{~b}$ & $8.6(1.6) b$ \\
\hline St & 100 & $0 \mathrm{c}$ & --- \\
\hline
\end{tabular}

$\overline{\mathrm{z}}(\mathrm{h})=$ Cheng's (1975); MS = Murashige and Skoog's (1962), St = Standardi's (1983).

'Mean separation within a column by Pearson's $\chi^{2}$ test at $P \leq 0.05$.

xMean separation within a column by $\mathrm{F}$ test at $P \leq$ 0.05 
velopment (Table 2). The combination of type II callus cultured on half-strength $\mathrm{K}(\mathrm{h})$ plus $2.25 \mu \mathrm{M}$ zeatin was the only treatment that resulted in $100 \%$ shoot bud formation. More shoot buds were formed on callus cultured on the $\mathrm{K}(\mathrm{h})$ than on the MS-based media (Table $2)$. The combination of $K(h)$ plus $4.5 \mu$ m zeatin provided the highest number of shoot buds with both types of subcultured explants. The best treatment for shoot development was the use of type-I explant cultured on full-strength $\mathrm{K}$ (h) medium plus $4.5 \mu \mathrm{m}$ zeatin (Table 2 ). Callus then was subcultured monthly onto $\mathrm{K}(\mathrm{h})$ medium plus $0.1 \mu \mathrm{M}$ IAA and $4.5 \mu \mathrm{M}$ zeatin without any decrease of its morphogenic potential.

Our results clearly show that $\mathrm{K}(\mathrm{h})$ medium (Cheng, 1975) was the best for morphogenic callus induction from petioles of in vitrogrown kiwifruit plants. This result agrees with our previous results with nodal segments from mature plants of this species (Rey et al., 1992), in which $\mathrm{K}(\mathrm{h})$ also was the best medium for morphogenic callus induction. This medium has the same macronutrient composition as MS medium (Murashige and Skoog, 1962), but its micronutrient and $\mathrm{Fe}$ concentrations are about half those in MS medium. Additionally, it has a more complex organic composition. All these differences can be related to the media's abilities to support adventitious bud formation from callus (Rey et al., 1992). St medium (Standardi, 1983) differs from the other media used principally in its macronutrient composition; $\mathrm{N}$ content and organic constituents are lower in St than in $\mathrm{K}(\mathrm{h})$ and MS media. However, micronutrient and Fe contents of St medium are about the same as in the $\mathrm{K}(\mathrm{h})$ medium. St medium has proven to be useful for direct morphogenesis in kiwifruit (Standardi, 1983; Revilla et al., 1992), but its ability to support morphogenic callus formation and proliferation is low (Rey et al., 1992).

Rooting in this species was possible, although at low rates $(22 \%$ rooting and 3.1 roots per rooted shoot after 30 days of culture), using microshoots cultured in half-strength $\mathrm{K}(\mathrm{h})$ basal medium. However, when the shoot bases were immersed in an IBA solution, an increased rooting percentage $(82 \%)$ and number of roots per rooted shoot (7.3) were obtained after 30 days of culture. Plant survival in the greenhouse was successfully achieved $(97 \%)$ independent of how the shoots were obtained (culture medium, type of callus).

We have devised an easy protocol for plant regeneration from petioles of in vitro-grown 'Hayward' kiwifruit plants. This protocol provides an alternative source of starting material from selected mature trees for transformation experiments. Using these explants, $\mathrm{K}(\mathrm{h})$ medium with $0.1 \mu \mathrm{M}$ IAA and $4.5 \mu \mathrm{m}$ zeatin was a good support for callogenic and morphogenic response. The induced calli can be proliferated successfully, providing a number of shoot buds that can be developed into shoots

Table 2. Effect of medium composition and type of subcultured explant on adventitious bud induction and development from petiole-derived callus of micropropagated kiwifruit in the presence of zeatin (4.5 or $2.25 \mu \mathrm{M})$ and $0.1 \mu \mathrm{M}$ IAA after 30 days of culture.

\begin{tabular}{lllcccc}
\hline \hline $\begin{array}{l}\text { Explant } \\
\text { types }^{\mathrm{z}}\end{array}$ & $\begin{array}{l}\text { Culture } \\
\text { medium }^{\mathrm{y}}\end{array}$ & $\begin{array}{c}\text { Zeatin } \\
\text { concn } \\
(\mu \mathrm{M})\end{array}$ & $\begin{array}{c}\text { Explants } \\
\text { forming } \\
\text { shoot buds }\end{array}$ & $\begin{array}{c}\text { Avg no. } \\
\text { shoot buds/ } \\
\text { explants (se) }\end{array}$ & $\begin{array}{c}\text { Explants forming } \\
\text { developed } \\
\text { shoots }(\%)\end{array}$ & $\begin{array}{c}\text { Avg no. } \\
\text { developed shoots/ } \\
\text { explant (sE) }\end{array}$ \\
\hline I & MS & 4.5 & $91^{\mathrm{x}}$ & $4.6(1.1) \mathrm{c}^{\mathrm{w}}$ & $17 \mathrm{~b}^{\mathrm{x}}$ & $2.0(1.0) \mathrm{a}^{\mathrm{w}}$ \\
& $\mathrm{K}(\mathrm{h})$ & 4.5 & 82 & $13.4(2.1) \mathrm{a}$ & $64 \mathrm{a}$ & $1.6(0.2) \mathrm{ab}$ \\
II & $\mathrm{MS}$ & 4.5 & 90 & $3.6(0.8) \mathrm{c}$ & $46 \mathrm{ab}$ & $1.0(0.0) \mathrm{b}$ \\
& $\mathrm{K}(\mathrm{h})$ & 4.5 & 75 & $11.4(0.6) \mathrm{ab}$ & $33 \mathrm{ab}$ & $1.3(0.3) \mathrm{ab}$ \\
& 1/2 MS & 2.25 & 73 & $5.1(1.2) \mathrm{c}$ & $27 \mathrm{ab}$ & $1.0(0.0) \mathrm{ab}$ \\
& 1/2 K(h) & 2.25 & 100 & $9.2(0.4) \mathrm{b}$ & $11 \mathrm{~b}$ & $1.0(0.0) \mathrm{ab}$ \\
\hline
\end{tabular}

${ }^{2}$ Explant types: $\mathrm{I}=$ callus plus part of the petiole; $\mathrm{II}=$ callus alone.

${ }^{y} \mathrm{~K}(\mathrm{~h})=$ Cheng's (1975); MS = Murashige and Skoog (1962).

'Mean separation within each column by Pearson's $\chi^{2}$ test at $P \leq 0.05$. Values followed by different letters are statistically different.

${ }^{\text {w } M e a n ~ s e p a r a t i o n ~ w i t h i n ~ e a c h ~ c o l u m n ~ b y ~ l e a s t ~ s i g n i f i c a n t ~ d i f f e r e n c e ~ t e s t ~ a t ~} P \leq 0.05$. Values followed by different letters are statistically different.

amenable to rooting and transfer to soil. Because transformation of kiwifruit does not seem to be a problem (Janssen and Gardner, 1993; Rugini et al., 1991; Uematsu et al., 1991), the way is open to the genetic improvement of this economically important species.

\section{Literature Cited}

Cheng, T.Y. 1975. Adventitious bud formation in culture of Douglas fir (Pseudotsuga menziesii Mirb. Franco). Plant Sci. Lett. 5:97-102.

Ferguson, A.R., A.G. Seal, and R.M. Davison. 1990. Cultivar improvement, genetics and breeding of kiwifruit. Acta Hort. 282:335-347.

Janssen, B-J. and R.C. Gardner. 1993. The use of transient GUS expression to develop an Agrobacterium-mediated gene transfer system for kiwifruit. Plant Cell Rpt. 13:28-31.

Leva, A.R. and F. Bertocci. 1988. The effect of sorbitol and mannitol on the morphogenesis of Actinidia deliciosa (A. Chev.) Liang and Ferguson callus. Acta Hort. 227:447-449.

Murashige, T. and F. Skoog. 1962. A revised medium for rapid growth and bioassays with tobacco tissue cultures. Physiol. Plant. 15:473497.

Predieri, S., B. Mezzetti, and R. Ranieri. 1988. Rigenerazione "in vitro" da foglie di Actinidia deliciosa cv. Hayward. Rivista Frutticoltura Ortofloricoltura 50(11):69-72.

Revilla, M.A. and J.B. Power. 1988. Morphogenic potential of long-term callus cultures of Actinidia. J. Hort. Sci. 63:541-545.

Revilla, M.A., M.A. Rey, F. Gonzalez-Rio, M.V. Gonzalez, C. Diaz-Sala, and R. Rodriguez. 1992. Micropropagation of kiwi (Actinidia spp.), p. 399-423. In: Y.P.S. Bajaj (ed.). Biotechnology in agriculture and forestry. vol. 18. High-tech and micropropagation II. Springer-Verlag, Berlin.

Rey, M., T. Fernández, V. González, and R. Rodríguez. 1992. Kiwifruit micropropagation through callus shoot-bud induction. In Vitro Cell. Dev. Biol. 28P:148-152.

Rugini, E., A. Pellegrineschi, M. Mencuccini, and D. Mariotti. 1991. Increase of rooting ability in the woody species kiwi (Actinidia deliciosa A. Chev.) by transformation with Agrobacterium rhizogenes rol genes. Plant Cell Rpt. 10:291295.

Standardi, A. 1983. La "micropropagazione" nella moltiplicazione dell'actinidia. Frutticoltura 45(2):17-22.

Uematsu, C., M. Murase, H. Ichikawa, and J. Imamura. 1991. Agrobacterium-mediated transformation and regeneration of kiwifruit. Plant Cell Rpt. 10:286-290. 